\title{
The Use of Audio-Visual Materials in the Education of Students with Hearing Loss
}

\author{
Elif Akay ${ }^{1}$ \\ ${ }^{1}$ Department of Special Education, Faculty of Education, Anadolu University, Eskişehir, Turkey \\ Correspondence: Elif Akay, Department of Special Education, Faculty of Education, Anadolu University, \\ Eskişehir, Turkey. E-mail: elifakay@anadolu.edu.tr
}

Received: February 23, 2021

Accepted: April 6, 2021

Online Published: June 23, 2021

doi:10.5539/ies.v14n7p1

URL: https://doi.org/10.5539/ies.v14n7p1

\begin{abstract}
Learning is the process of restructuring mental schemas through adaptation to new experiences. Instructional materials help form a suitable and individualized educational environment for students with hearing loss while facilitating lexical development and comprehension of academic content. This case study aims to demonstrate the contribution of visual and audiovisual materials to the efficiency of the Social Studies Course for 4th-grade students with hearing loss. Findings of the study have been collected through video recordings of the lessons, validity meetings, the research log, realia, photographs/images, graphic organizers, and educational videos/documentaries. Data analysis demonstrates that the use of visual and audiovisual materials contributes substantially to students' (a) comprehension of the questions and explanations, (b) participation in and drawing conclusions from classroom discussions, and (c) understanding of new vocabulary and concepts. Based on the results, it can be argued that the use of visual and auditory materials presented so as to cater to the individual needs of the students, together with various educational strategies, provides significant advantages in the acquisition of academic knowledge by students with hearing loss.
\end{abstract}

Keywords: hearing loss, visual materials, audiovisual materials, social studies, listening-understanding

\section{Introduction}

Learning is a dynamic cognitive process involving the formation and structuring of new schemas through perception, interpretation and categorization of new information and experiences. Throughout the process, existing knowledge is integrated with new information. Since previous knowledge and experience affect the acquisition of new ones, the meaning ascribed to the concept amounts to the personal learning level (Neumann \& Kopcha, 2018). Therefore, the provision of a learning environment tailored to students' individual characteristics facilitates the improvement of the vocabulary range and the understanding of academic content through information and experience. Instructional materials employed in the process are among the significant factors affecting the concretization and retention of concepts while enabling the formation of an active learning environment and the acquisition of new experiences (Whitby et al., 2012). Due to the latency in their language skills, students with hearing loss have a greater need for the concretization of academic information and terminology, first-hand experience of new information in a variety of contexts, and direct teaching of the instructional strategies (Karasu, 2020; Kyle et al., 2016). Therefore, teachers need to use instructional materials while asking questions, giving explanations or definitions, and initiating educational debates (Sharan, 2015). Instructional materials can be categorized as (a) written, (b) visual, and (c) audiovisual materials (Brophy \& Alleman, 2009). This paper focuses on the realia, photographs/images, graphic organizers, and educational videos/documentaries among the visual and audiovisual materials used in the Social Sciences Course for students with hearing loss.

The most common materials used in educational environments are printed materials such as course books, magazines, newspapers, encyclopedias and similar documents, all of which require the acquisition of new information through reading. When printed materials cover events and abstract concepts that the students cannot experience, mere literary skills fail the student in understanding the content. As such, in order to understand the printed materials in the coursebooks, primary school students need to engage in group debates where they can use their own experience, gain new ones and employ their problem-solving skills (Bickford et al., 2015) which will enable them to create mental schemas concerning the concepts related to the course content (Neumann \& 
Kopcha, 2018).

Visual materials can be exemplified as realia, models, photographs, posters, fliers, maps and graphic organizers (Brophy \& Alleman, 2009). These materials provide clues for students with and without hearing loss to access information and participate in the discussions (Luckner et al., 2001) while contributing to their problem-solving skills (Nikolaraizi et al., 2013). It is essential that these materials are suitable to improve the cognitive development and verbal skills of students with and without hearing loss (Graham et al., 2015). Realia and photographs/images are visual resources that are directly linked to the subject matter. They enable students to establish connections between objects, develop critical thinking skills about concepts, and acquire questioning skills by comparing the past and the present (Zarrillo, 2012). Graphic organizers, on the other hand, are used to summarize information obtained by using realia and photographs/images. Graphic organizers such as menus, logos, lists, and concept maps help students prepare for daily life and promptly remember the connections between events while supporting knowledge retention (Luckner et al., 2001; Ponce et al., 2019).

Audiovisual materials encompass educational videos, documentaries and movies (Brophy \& Alleman, 2009). These materials are mainly used to demonstrate events that are difficult, dangerous or even impossible to experience in real life. Educational videos facilitate students' inferencing skills by exemplifying real-life events (Siagian et al., 2019). While documentaries offer evidence by connecting events with historical documents, movies trigger emotional reactions in the audience in the face of real experiences and propose a fictional demonstration of the past (Marcus et al., 2018). Field trips to educational environments offer essential opportunities for on-the-spot observations and experiences. These trips stimulate all sensory organs, the association of the subject matter with real-life and on-the-spot experiencing of the events (Kudryavtsev et al., 2012).

In the international literature, there are numerous studies on the use of visual and audiovisual materials in the education of students with special needs and their peers with normal physiological development. These studies employ various materials such as realia, cartoons, images, shapes, photographs, puppets, newspapers, computers, videos, sound records, animations and dramatizations. Research confirms that visual and audiovisual materials facilitate the expansion of vocabulary range (Dugan et al., 1995; Graham et al., 2015; Keser \& Özdemir, 2018; Saripudin et al., 2014), understanding of the new information, participation in classroom discussions, interaction in the classroom, and skills development in questioning and reading (Stinson \& Liu, 1999; Triarini et al., 2017). However, research into facilitating access to academic information through materials use for students with hearing loss seems limited. International research into the contribution of visual and audiovisual materials started 30 to 40 years ago. These studies primarily focused on printed materials and used informative texts that are appropriate to the reading skills levels in the form of structured printed materials such as task cards and worksheets. As a result, it was found out that these texts supported the understanding and retention of abstract concepts and the expansion of the students' vocabulary range (Diebold \& Waldron, 1988; Reynolds \& Rosen, 1973; Triarini et al., 2017).

Turkey has been applying the constructivist approach in its national education program that encourages active participation since 2005. However, most of the research conducted in Turkey concludes that, in their efforts to make information accessible, teachers heavily depend on the coursebook rather than materials that help students concretize information. This paper examines the impact of rich visual and audiovisual material presentation to children with hearing loss in a developing country such as Turkey. It is believed that the findings will not only display the challenges that students with hearing loss face but also exemplify the use of materials tailored for students' special needs while highlighting the importance of the visual and audiovisual materials. The instructional practices that help students create mental schemas related to the Social Studies concepts can also be expected to facilitate learning in other academic fields such as reading, writing and mathematics. The overall aim of this study is to examine the impact of the use of visual and audiovisual materials on 4th-grade students with hearing loss in the Social Studies course. As such, it aims to answer the question, "How do visual and audiovisual materials assist students with hearing loss in learning the concepts of the Social Studies course?"

\section{Method}

This research is a descriptive case study aiming to demonstrate the contribution of visual and audiovisual materials to the Social Studies course for 4th-grade students with hearing loss. A case study is an in-depth examination of a subject or a phenomenon in its natural context and state without any interference (Yin, 2012).

\subsection{Educational Environment}

This research was carried out at the Center for Educational Research and Practice for Hearing-Impaired Children (ICEM) at Anadolu University. ICEM offers family education in addition to preschool, primary and secondary school level education to students with hearing loss through the auditory-oral approach after early diagnosis and provision of assistive devices. The center also carries out reverse mainstreaming practices in the preschool period 
and provides support education services to students who are directed to inclusion at primary and secondary school levels.

\subsection{Participants}

The participants in the study are eight students with hearing loss currently in the 4th grade at ICEM. Four participants have profound hearing loss, whereas three have severe and one has moderately severe hearing loss. The age that students started using hearing aids ranges from 8 months to 2 years and 11 months. According to the information obtained from the center's audiology and psychology clinics, students do not have any additional diagnosed disabilities. All the students received Family Education immediately after diagnosis. Per ethical principles, families were informed about the research in advance and gave their written consent. In the research findings, the students are referred to by aliases. The person referred to as the teacher in the study is a researcher with 24 years of hearing-impaired teaching experience.

\subsection{Data Collection Process}

The variety of data collection tools in case studies is vital for their validity and reliability (Yin, 2012). In this study, data was collected through process products consisting of video recordings of courses, interview records of the validity committee, lesson plans, research log, realia, photos/images, graphic organizers and educational videos/documentaries/movies. The research was carried out between $26^{\text {th }}$ February 2018 and $20^{\text {th }}$ April 2018 in the second semester of the 2017-2018 academic year. Various teaching materials were used in "Science, Technology and Society," "Production, Distribution and Consumption," and "Effective Citizenship" units, respectively, for seven weeks in the social studies course. A scatter chart of materials by units is presented in Figure 1.

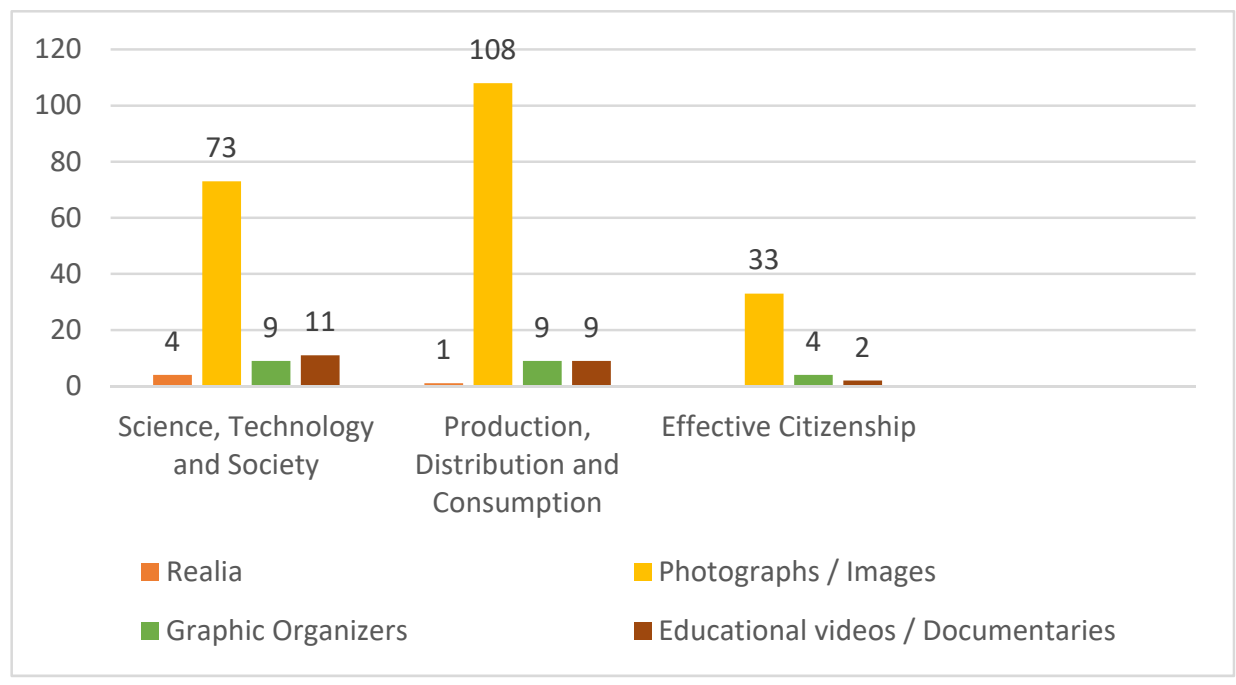

Figure 1. Scatter chart of teaching materials in units

As shown above, four categories of instructional material were used in this research: (a) realia, (b) photographs/images, (c) graphic organizers, and (d) educational video/documentary. These materials were selected so as to meet the students' needs, considering the goals of Social Studies, and different categories of materials were used together in the courses. Materials and the number of materials are presented by units and categories In Table 1. 
Table 1. Materials and the number of materials are presented by units and categories

\begin{tabular}{|c|c|c|c|c|c|}
\hline & & Science, Technology and Society & $\begin{array}{c}\text { Production, Distribution and } \\
\text { Consumption }\end{array}$ & Effective Citizenship & Total \\
\hline \multirow{3}{*}{ 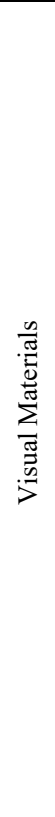 } & 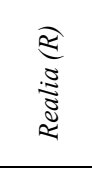 & $\begin{array}{l}\text { 1. Computer (1) } \\
\text { 2. Mobile Phone (1) } \\
\text { 3. Clock (1) } \\
\text { 4. Light Bulb (1) }\end{array}$ & 5. Milk carton (1) & - & 5 \\
\hline & 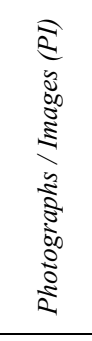 & $\begin{array}{l}\text { 1. Advances in the Field of Health } \\
\qquad \text { (12) } \\
\text { 2. Advances in the Field of } \\
\text { Education (5) } \\
\text { 3. Historical Development of } \\
\text { Transportation and the Wheel (29) } \\
\text { 4. Means of Communication (15) } \\
\text { 5. Benefits of Technology (12) }\end{array}$ & $\begin{array}{l}\text { 6. Basic and Social Wants and } \\
\text { Needs (27) } \\
\text { 7. Production Activities (29) } \\
\text { 8. I Choose My Profession (29) } \\
\text { 9. Characteristics of Professions } \\
\text { (10) } \\
\text { 10. Saving and Squandering (13) }\end{array}$ & $\begin{array}{l}\text { 11. I Want to Join Students' } \\
\text { Societies (9) } \\
\text { 12. Non-Governmental } \\
\text { Organizations (13) } \\
\text { 13. Governance in Our } \\
\text { Country (11) }\end{array}$ & 214 \\
\hline & 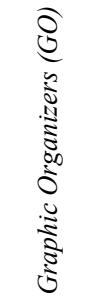 & $\begin{array}{l}\text { 1. Table of Inventors (1) } \\
\text { 2. Timeline of Inventions (7) } \\
\text { 3. World Map (1) }\end{array}$ & $\begin{array}{l}\text { 4. Professions (1) } \\
\text { 5. Table of Economic Activities (1) } \\
\text { 6. Budget Table (1) } \\
\text { 7. Certificate of Warranty (1) } \\
\text { 8. Electric Bill (1) } \\
\text { 9. Posters (4) }\end{array}$ & $\begin{array}{l}\text { 10. Declaration of the Right } \\
\text { of the Child (1) } \\
\text { 11. Poster (1) } \\
\text { 12. Fliers (1) } \\
\text { 13. Map of Turkey (1) } \\
\text { 14. Governance in Our } \\
\text { Country (1) }\end{array}$ & 23 \\
\hline 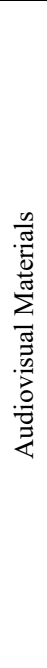 & 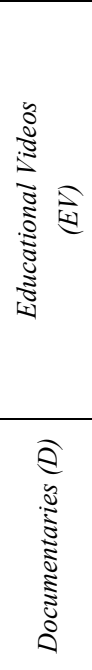 & $\begin{array}{l}\text { 1. Technological Devices (1) } \\
\text { 2. Technology from the past to the } \\
\text { present (1) } \\
\text { 3. Development of Transportation } \\
\text { (1) } \\
\text { 4. Development of Communication } \\
\text { (1) } \\
\text { 5. Development of the Computer } \\
\text { (1) } \\
\text { 6. Uses of Technology (1) } \\
\text { 1. Historical Development of the } \\
\text { Wheel (1) } \\
\text { 2. Invention of the Light Bulb (1) } \\
\text { 3. Invention of the Telephone (1) } \\
\text { 4. Invention of the Radio (1) } \\
\text { 5. Invention of the Plane (1) }\end{array}$ & $\begin{array}{l}\text { 7. Our Wants and Needs (1) } \\
\text { 8. Basic and Social Needs (1) } \\
\text { 9. Economic Activities (1) } \\
\text { 10. Professions (1) } \\
\text { 11. Features of Products (1) } \\
\text { 12. Budget in Shopping (1) } \\
\text { 13. Consumer Rights (1) } \\
\text { 14. Saving and Squandering (1) }\end{array}$ & $\begin{array}{l}\text { 15. Student Societies (1) } \\
\text { 16. Digital Coding (1) }\end{array}$ & 22 \\
\hline
\end{tabular}

As shown in Table 1, a total of 264 materials were used, including 5 in the category of realia, 214 in the category of photos/images, 23 in the category of graphic editors, and 22 in the category of educational videos/documentaries. Documentaries were viewed from the YouTube channel, and the Vitamin Interaktif Egitim Platform was used to access educational videos.

While determining the materials used in the research process, utmost attention was paid to ensure that they were directly related to the goals of the course and real-life and that they offered clues to the students about the words and concepts to make comparisons. Visual and audiovisual materials were examined before the lesson with a field specialist to determine the sections that students may have difficulty understanding and the ones that should be emphasized. During the application, educational videos and documentaries were paused from time to time to accommodate discussions on the causal relationship between events so that students could get accurate impressions.

\subsection{Analysis of the Data}

Research data was obtained from 33 Social Studies courses, and representative videos were determined for use as part of the data analysis. The researcher worked with a field specialist in the process in which research data was examined, and applications were selected to reflect the use of visual and audiovisual materials in detail. The 
information concerning the date, duration, and content of representative videos are presented in Table 2 .

Table 2. The date, duration, and content of the representative videos

\begin{tabular}{cccc}
\hline Video & Date & Duration & Content \\
\hline V1 & 02.03 .2018 & $50^{\prime} 30^{\prime \prime}$ & Technology from Past to Present (Wheel) \\
V2 & 07.03 .2018 & $50^{\prime} 29^{\prime \prime}$ & Technology in Time \\
V3 & 20.03 .2018 & $50^{\prime} 39^{\prime \prime}$ & Be Conscious Consumers (Packaged Products) \\
V4 & 27.03 .2018 & $50^{\prime} 25^{\prime \prime}$ & Cut Your Coat According to Your Cloth \\
\hline
\end{tabular}

As part of the data analysis, a breakdown of representative videos and eight validity meetings was made, and the data was analyzed descriptively. The analysis documented the contribution of the use of visual and audiovisual materials for students in Social Studies courses in (a) understanding explanations and questions, (b) participating in discussions and drawing conclusions, and (c) understanding words and concepts.

\subsection{Validity and Reliability}

The validation of the study involved two field experts with 39 and 26 years of experience in the education of students with hearing loss and qualitative research methods. The validity committee examined the diversity of data collection tools, lesson plans, materials, researcher's log, video recordings of lessons, and a breakdown of recordings. Besides, representative videos were viewed to evaluate the reliability of the themes, and the committee reached a $98 \%$ consensus.

\section{Findings}

In this research, realia, photos/images, graphic organizers and educational videos/documentaries were used together in Social Studies courses. Photos/images and educational videos/documentaries were viewed on the interactive board in the classroom. The photos/images suitable for the course were selected before the lesson and organized as a presentation. Educational videos/documentaries were viewed before the course, and they were cut to fit in the duration of the course. The contribution of visual and audiovisual materials to the learning of students with hearing loss are presented below under the themes (a) understanding explanations and questions, (b) participating in discussions and drawing conclusions, and (c) understanding words and concepts.

\subsection{Visual and Audiovisual Materials and Their Contribution to Understanding Questions}

Visual and audiovisual materials offered clues to support the students' understanding of explanations and questions. For instance, in the Science Technology and Society unit, a documentary on Marconi's invention of the radio was viewed as part of the section Technology Over Time (Table 1, D-4). This documentary features photographs and dramatizations showing Marconi's home and his work on the invention of the radio. On seeing a photo of Marconi's house, Tülin and Murat asked if it was close to Eskişehir. Students were then shown Italy on the world map, and they assessed the distance between Italy and Turkey (Table 1, GO-3). The documentary demonstrates Marconi's prolonged work through photographs. In order to assess how the students benefited from the explanations, the video was stopped, and the students were asked questions like "What is an antenna used for?" and "Why does Marconi go to higher ground with the antenna?" Some students were observed to answer these questions by using clues from the documentary. Some students, on the other hand, needed further explanation, which required stopping the video and showing specific images or scenes from the documentary. After understanding the questions and finding the answers, the students were able to predict that the antenna would be used to operate the radio. In order for students to integrate all the information they had learned, the teacher wrote Marconi's first name, last name, date and place of birth, and his invention on the timeline with the students' participation (Table 1, GO-1). This table also contains information about other inventors studied since the beginning of the unit. By looking at the table, the students were able to infer that Edison and Marconi lived in different countries. However, when comparing the birth dates of Marconi (1874) and Edison (1847), they could not agree on who was older (Table 2, V2, 12'40'). Therefore, the students were asked to place Marconi's photo and the information in the table on the timeline (Table 1, GO-2). The students determined that the year 1874 was a date closer to the present and were able to place Edison after Marconi in the timeline. In this course, the teacher used a documentary to portray the past, a map to demonstrate distance, a table to highlight important information, and a timeline to show the sequence of events. Nevertheless, students found it challenging to understand the explanations about the period of time that the inventors lived. Students also needed a visual clue to understand questions about the function of an antenna. 
At the end of the course, students were asked, "What are the characteristics of inventors?" This question requires inference by generalizing. Mehmet recalled the photos in the documentary showing Marconi's work to invent the radio and replied, "Inventors do many experiments. They invent technological tools." "They read books all the time and learn new information," Rutkay contributed, recalling photos of Marconi in his study. Ufuk, on the other hand, recalled the photo of the first radio and joined in by saying, "They can make a machine that no one knows about" (Table 2, V2, 45'32'). As seen in the example, some of the students were able to generalize the events when various materials were provided. Some, however, needed to repeat the subjects in another lesson to better understand the course content. Therefore, it can be said that this lesson laid the groundwork for subsequent lessons.

\subsection{Contribution of Visual and Audiovisual Materials to Participation and Inference in Discussions}

Visual and audiovisual materials allowed students with hearing loss to draw conclusions and make comparisons by picturing events in their minds. For instance, the historical development of the wheel over time was discussed in the Science Technology and Society unit under the topic The Development of Technology Over Time. A presentation containing photographs of wheels made of stone, wood, slate, metal and rubber was prepared (Table 1, PI-3) and shown on the interactive board. The students were able to start the discussion by saying that the first wheels were made of stone and guessed that the stone wheels could be heavy. Visual materials showing the tools used in the past have provided the opportunity for students to self-correct their misconceptions. For example, Murat participated in the discussion by predicting that a hole was drilled in the middle of the stone wheel with a hammer (Table 2, V1, 03'38'). The students were told that there were no hammers at the time stone wheels were made. In order to help the students understand the explanation, photos of stone tools used in the construction of stone wheels were shown on the interactive board over the internet. Some students were able to infer that it would be very difficult and take a lot of time to drill a hole in the stone with the tools in the photo. Some asked when the wheel was invented (Table 2, V1, 05'02'). It was necessary to concretize that the wheel was invented in ancient times. For this, students were shown pictures depicting the first people, and then the period that these people lived in was marked at the starting point of the timeline (Table 1, GO-2). Students were encouraged to make comparisons so that they could draw conclusions. Students could not be expected to make spontaneous comparisons without using photos depicting the development of the wheel. For this reason, students were asked to compare the stone wheels in the photos and the rubber wheels used today in order to understand the differences between them. As a result, students were able to conclude that the wheels used today are lighter than the old wheels, using their knowledge of stone and rubber materials. In addition, by looking at the photos of old tools, they concluded that stone could not be shaped properly in the past and that today more robust wheels could be made easily and quickly with machines (Table 2, V1, 28'36').

\subsection{Contribution of Visual and Audiovisual Materials to Understanding Words and Concepts}

Visual and audiovisual materials enable students to learn the meaning of words, to understand abstract words, and to gain in-depth knowledge about these words. For instance, a training video about products' features was used in the Production, Distribution, and Consumption unit while discussing the topic Be Conscious Consumers (Table 1, EV-11). It was stated at the beginning of the course that packaged products would be the topic of discussion for that day. Tulin, Murat and Tarkan stated that they did not know the meaning of the word "packaged" (ambalaj). After seeing the animation in the educational video, they were able to exemplify packaged products as "cheese, sausage, ice cream" (Table 2, V3, 18'23'). Students knew that food was sold in packages, but it was necessary to explain that "packaging" was used to protect products. They were shown an educational video that explained what they should pay attention to while buying packaged products. The educational video was stopped from time to time, and the students were asked to describe what they were watching to demonstrate the extent that they understood what they saw in the video. Characteristics of packaged products have been discussed using realia, such as the written information on the milk box to examine critical issues about buying packaged products (Table 1, R-5). The milk box was chosen because it is the packaged product that students encounter most often in their daily lives. All the students acknowledged that the packaged product they were shown was a milk box and was sold in grocery stores. Mehmet explained that the milk is packaged so that it does not go sour (Table 2, V3, 20'20'). When the expiration date, place of production, and TSE symbol on the milk box were read, students were unable to understand the information. The expiration date, the place of production, and the location of the TSE symbol in the milk box were explained over the educational video. After the video, İbrahim came up with the statement, "The milk tastes bad after the expiration date," and Rutkay contributed by saying, "We should make sure that the milk box is intact" (Table 2, V3, 19'25"). Students were able to understand the meaning of the TSE symbol when shown a photo of people studying in the laboratory.

Another example of the contribution of visual and audiovisual materials to understanding words was observed in the Production, Distribution and Consumption unit. The section titled Cut Your Coat According to Your Cloth in 
the Production, Distribution and Consumption unit covered the concepts of "saving" and "budget." To discuss the word "saving," students were shown an educational video with discarded food and animations of lamps that were left on and taps that were left running (Table 1, EV-14). Using the video, the students were able to state that food and drinks should not be thrown in the trash, that the lamp and water should be turned off after use; otherwise, they would run out of money (Table 2, V4, 13'02'). This material support was found to be sufficient for students to understand the new information using their past knowledge and experience. It was then explained to the students that it was necessary to prepare a budget to be able to afford things. Students were not able to explain the word "budget." The students were then asked to list the basic needs (food, housing, and clothing) they had learned at the beginning of the unit. Students listed basic needs and stated that they needed food for nutrition, clothes for clothing, and rent for housing (Table 2, V4, 22'07'). A concept map for the budget was created using these contributions (Table 1, GO-6). They were then shown an electricity bill and asked what the bill was for (Table 1, GO-8). When Murat and Ufuk saw the electricity bill, they said, "We pay the electricity money when we get the electricity bill" (Table 2, V4, 25'20"). In order for students to understand that the electricity bill has a monetary value, the section with the amount owed was shown, and the date of the bill was noted, explaining that it is paid every month. Students were able to connect this information to telephone and natural gas bills using the example of electricity bills (Table 2, V4, 25'33'). These contributions of students were classified under the basic needs in the budget concept map.

\section{Discussion}

It is noted that the most persistent information in the transition of information from stimuli around us to long-term memory is information coming through visual and auditory channels (Neumann \& Kopcha, 2018). Therefore, visual and audiovisual materials are of great importance in teaching the subjects and concepts in the educational program. A variety of research highlights the contribution of teaching materials used in Social Studies to general and special education (Bickford et al., 2015; Steele, 2008; Triarini et al., 2017). These studies mainly focus on the challenges of understanding the printed materials and the adaptation of written texts used in the Social Studies course. But in order to understand the information in printed materials, it is necessary first to form schemas for concepts in our minds (Luckner et al., 2001; Neumann \& Kopcha, 2018). Piaget (1951) emphasizes that schemas for concepts in our minds can develop only as a result of interaction with the environment (as cited in Duncan \& Redwine, 2019). Schemas can only be changed and expanded with new information. Therefore, it is essential in educational settings to provide students with opportunities to make sense of the content by integrating the new information with past knowledge (Steele, 2008). Students with and without hearing loss need visual and audiovisual materials to use knowledge and experience in an educational environment and form schemas (Luckner et al., 2001). Also, students with hearing loss need field-specific information and terminology to be concretized and repeated more than their hearing peers (Karasu, 2020; Kyle et al., 2016). To this end, in this study, the teacher used realia, and discussions were conducted over photos/images to support the creation of schemas for social studies concepts in the minds of students with hearing loss. Graphic organizers such as timelines, tables, and concept maps were created, and educational videos/documentaries were shown where students could use the words they learned. In this way, students were presented with evidence from the temporary and past life, information was summarized, and the learning environment was diversified.

It is important that these visual and audiovisual materials used in educational settings are appropriate to the objectives and duration of the course (Johnson et al., 2011). The materials in this research were specifically chosen to include concepts in the course objectives. For example, "making a budget" is a concept intended to be acquired in the Production, Distribution and Consumption unit. This concept is something that the student observes in the family but is often not involved. For this reason, in order to understand the budget concept, actual documents such as electricity, water and natural gas bills and expenses based on basic needs such as food, drinking and housing were examined. The authentic material was needed so that students could read the electricity bill. Graphic organizers about expenses were created for the students to understand the rich content of the concept. Visual and audiovisual materials were observed to provide clues to the teacher's explanations and questions while offering the students with hearing loss the opportunity to express their thoughts. This finding is in line with those of Dugan et al. (1995), who state that visual materials contribute to understanding the explanations and the questions in the course. Concepts in this unit, such as savings, budget, and rent cannot be shown physically to students. Accordingly, these concepts have been presented in association with the concepts of money, bills, shopping and housing. Despite all visual material support, though, it should be noted that the students could understand the knowledge about these concepts only to the extent of their past knowledge and experience.

Another contribution of visual and audiovisual materials is to enable students with hearing loss to make inferences and participate in educational discussions using their knowledge and experience (Sharan, 2015; Whitby et al., 
2012). Stinson and Liu (1999) have determined that providing various visual resources allows 4 th-grade students with hearing loss to participate in discussions in mainstream classrooms. The current study focuses on students with hearing loss in a self-contained classroom. Research results show that visual and audiovisual materials contribute to students' ability to use their knowledge and experience and participate in discussions. Based on both research results, it can be said that it is important to use visual and audiovisual materials to facilitate the academic development of students with hearing loss in different educational settings.

Visual and audiovisual materials also facilitate the concretization of concepts, vocabulary development, acquisition, and retention of lasting knowledge (Whitby et al., 2012). Graham et al. (2015) demonstrate that the use of textbooks, as well as images, blackboard, computer, videos and audio cassettes in the teaching of multi-component vocabulary in the Social Studies lessons for the 4th-grade hearing students supports the development of vocabulary. In the current research, similar materials such as photos/images, educational videos/documentaries, as well as realia have been used so that students can directly relate the target vocabulary to their daily lives during their study of social studies concepts. In another study with hearing secondary school students, Saripudin et al. (2014) emphasize that presenting students with concepts about their local environment and culture through visual and audiovisual sources such as presentations, cartoons, pictures, shapes, pictures, puppets and audiovisual resources contribute to learning in Social Studies courses. In the current study, audiovisual sources such as documentaries and educational videos were also used to teach the concepts of Social Studies courses to 4th-grade students with hearing loss. Concepts that were studied covered "consumption, economic activity, budget, radio wave, bill, technology," which are not part of the vocabulary range of participating students with hearing loss. Triarini et al. (2017) confirm that two-and three-dimensional multimedia materials, animations and realia contribute to the development of the vocabulary range of students with hearing loss. In this research, computers, mobile phones, watches, light bulbs and milk boxes were used as realia to develop vocabulary. Hence, participating students were able to join in the discussion using their existing knowledge about the milk box. However, the students needed their teacher's help to understand the consumer information on the top of the box. Unlike the research by Triarini et al. (2017), graphic organizers were also used to help students understand the relationships between words in this research.

Yusuf et al. (2017) applied a concept learning model in their research with 7th-grade students with hearing loss in the Social Studies courses. They observed that students chose keywords for the subject by using visual and audiovisual materials and that such materials contributed to concept development. In the current research, it has been noted that visual materials contribute to the learning of selected words such as savings, budget, packaging in the Social Studies courses. In this research, the visual and audiovisual materials were chosen specifically to be contextual and the events to be interrelated in order for the knowledge of concepts to be permanently acquired by the 4th-grade students with hearing loss. It is noted that realia and photos/images enable students to establish connections between objects and gain questioning skills by making comparisons (Zarrillo, 2012). It is safe to argue that the realia used in this study allowed students with hearing loss to make comparisons between the past and the present. For example, while studying the history of the wheel, examining photos of modern wheels on an interactive board and from an encyclopedia allowed students to use their current knowledge and compare the change in the wheels used in the past. Students were, thus, able to make explanations on the subject and make more accurate and quicker predictions.

Educational videos support students' inferencing skills by reflecting real-life events (Johnson et al., 2011). However, this achievement depends heavily on the use of materials such as educational videos and documentaries with face-to-face interaction (Marcus et al., 2018). In this study, the teacher viewed educational videos and documentaries in advance, determined the sections to be highlighted, adjusted the length of the videos to fit in the duration of the lesson, and planned lessons accordingly. After due preparation, training videos and documentaries were viewed during the lessons and stopped at times to create an opportunity for face-to-face discussions. It is believed that case studies and documentaries in educational videos used in this study offer significant contributions to students with hearing loss in understanding the causes of events, discussing them, making comparisons, and arriving at conclusions by acquiring new experiences.

Documentaries, educational videos and some photos are presented over an interactive board. The literature demonstrates that interactive boards facilitate access and presentation of materials while supporting students' academic skills by increasing motivation (Min \& Siegel, 2011). In this study, it was found that the interest and motivation levels of the participating students increased when educational videos/ documentaries were viewed from the interactive board. Notwithstanding, a similar increase has also been observed in discussions over photos in printed magazines and encyclopedias. This can be explained by students' overall tendency to follow, understand, and enjoy discussions with visual and audiovisual materials, regardless of whether they are printed 
or digital.

Research highlights the need to use visual materials focused on active learning (Easterbrooks \& Stephenson, 2006) and implement instructional strategies appropriate to individual needs so that students with hearing loss can improve their cognitive skills (Antia et al., 2002). The Science, Technology and Society Unit discussed in this research focuses on developing change and innovation skills, and the Production, Distribution and Consumption unit focuses on developing financial literacy skills (MEB, Social Studies Program, 2018, p. 14). It can be contended that the materials, technological realia, and documentaries about inventors used in the research offer the opportunity to use change and innovation skills. It is also believed that graphic organizers on budgeting and economic activities contribute to students' financial literacy.

\section{Conclusion}

This study used realia, photos/images, graphic organizers, educational videos, and documentaries to support students with hearing loss to learn the Social Studies course content. Based on the results, it can be argued that the use of visual and auditory materials presented so as to cater to the individual needs of the students, together with various educational strategies, provides significant advantages in the acquisition of academic knowledge by students with hearing loss.

This research is limited to the units, subjects, number of participants and materials used in Social Studies courses. In order to increase the contribution of this research and to ensure the permanence of knowledge by combining it with life, more realia can be used in the teaching process, educational trips can be organized to places where the event for content takes place, and concepts can be associated with topics in other courses. In future research, the effects of visual and audiovisual materials on learning can be studied with a greater number of participants in various educational settings and quantitative analysis.

\section{References}

Antia, S. D., Stinson, M. S., \& Gaustad, M. G. (2002). Developing membership in the education of deaf and hard-of-hearing students in inclusive setting. Journal of Deaf Studies and Deaf Education, 7(3), 214-229. https://doi.org/10.1093/deafed/7.3.214

Bickford, J. H. III, Dilley, D., \& Metz, V. (2015) Historical writing, speaking, and listening using informational texts in elementary curricula. The Councilor: A Journal of the Social Studies, 76(1), 1-16. Retrieved from https://thekeep.eiu.edu/the_councilor/vol76/iss $1 / 2$

Brophy, J., \& Alleman, J. (2009) Meaningful social studies for elementary students. Teachers and Teaching: Theory and Practice, 15(3), 357-376. https://doi.org/10.1080/13540600903056700

Diebold, T. J., \& Waldron, M. B. (1988). Designing instructional formats: the effects of verbal and pictorial components on hearing-impaired students' comprehension of science concepts. American Annals of the Deaf, 133(1), 30-35. https://doi.org/10.1353/aad.2012.0679

Dugan, E., Kamps, D., Leonard, B., Watkins, N., Rheinberger, A., \& Stackhaus, J. (1995). Effects of cooperative learning groups during social studies for students with autism and fourth-grade peers. Journal of Applied Behaviour Analysis, 28(2), 175-188. https://doi.org/10.1901/jaba.1995.28-175

Duncan, T., \& Redwine, R. (2019). Shifting schemas: Perspectives and practice in a learner-centered course. International Journal of Teaching and Learning in Higher Education, 31(1), 154-165. Retrieved from http://www.isetl.org/ijtlhe/

Easterbrooks, S. R., \& Stephenson, B. (2006). An examination of twenty literacy, science, and mathematics practices used to educate students who are deaf or hard of hearing. American Annals of the Deaf, 151(4), 385-397. https://doi.org/10.1353/aad.2006.0043

Graham, L., Graham, A., \& West, C. (2017). From research to practice: The effect of multi-component vocabulary instruction on increasing vocabulary and comprehension performance in social studies. International Electronic Journal of Elementary Education, 8(1), 147-160. Retrieved from https://iejee.com/index.php/IEJEE/article/view/103.

Karasu, H. P. (2020). Development of emergent literacy skills of a child with hearing loss: A longitudinal case study. Educational Studies, 46(5), 513-531. https://doi.org/10.1080/03055698.2020.1745623

Keser, H., \& Ozdemir, O. (2017). Examination of the Use of Computer Aided Word Teaching Material for the Education of Students with Hearing Impairment. Ankara University Faculty of Educational Sciences Journal of Special Education, 19(1), 29-53. https://doi.org/10.21565/ozelegitimdergisi.300290 
Kudryavtsev, A., Krasny, M. E., \& Stedman, R. C. (2012). The impact of environmental education on sense of place among urban youth. Ecosphere, 3(4), 1-15. https://doi.org/10.1890/ES11-00318.1

Kyle, F. E., Campbell, R., \& MacSweeney, M. (2016). The relative contributions of speechreading and vocabulary to deaf and hearing children's reading ability. Research in Developmental Disabilities, 48, 13-24. https://doi.org/10.1016/j.ridd.2015.10.004

Lang, H. G., \& Propp, G. (1982). Science education for hearing-impaired students: State-of-the-art. American Annals of the Deaf, 127(7), 860-869. https://doi.org/10.1353/aad.2012.1174

Luckner, J., Bowen, S., \& Carter, K. (2001). Visual teaching strategies for students who are deaf or hard of hearing. Teaching Exceptional Children, 33(3), 38-44. https://doi.org/10.1177/004005990103300306

Marcus, A. S., Metzger, S. A., Paxton, R. J., \& Stoddard, J. D. (2018). Teaching History with Film: Strategies for Secondary Social Studies (2nd ed.). Routlegde. https://doi.org/10.4324/9781351137737

Min, K., \& Siegel, C. (2011). Integration of SMART board technology and effective teaching. GSEAP Faculty Publications: 54 . https://doi.org/10.26634/jsch.7.1.1518

Ministry of National Education. (2018). Social Studies Teaching Program. MEB. Retrieved from https://mufredat.meb.gov.tr/Dosyalar/201812103847686-SOSYAL\%20B\%C4\%B0LG\%C4\%B0LER\%20\% C3\%96\%C4\%9ERET\%C4\%B0M\%20PROGRAMI\%20.pdf

Neumann, K. L., Kopcha, T. J. (2018). The use of schema theory in learning, design, and technology. TechTrends 62, 429-431. https://doi.org/10.1007/s11528-018-0319-0

Nikolaraizi, M., Vekiri, I., \& Easterbrooks, S. R. (2013). Investigating deaf students' use of visual multimedia resources in reading comprehension. American Annals of the Deaf, 157(5), 458-474. https://doi.org/10.1353/aad.2013.0007

Ponce, H. R., Mayer, R. E., Loyola, M. S., \& Lopez, M. (2020). Study Activities That Foster Generative Learning: Notetaking, Graphic Organizer, and Questioning. https://doi.org/10.1177/0735633119865554

Reynolds, H. N., \& Rosen, R. F. (1973). The effectiveness of test book, individualized, and pictorial instructional formats for hearing impaired college students. Annual meeting of the American Educational Research Association. New Orleans, Louisiana, February 25-March 1. Retrieved from https://files.eric.ed.gov/fulltext/ED075968.pdf

Saripudin, D., Komalasari, K., \& Moeis, S. (2014). The development of students' sociocultural values through wayang golek as a learning source in social studies. Research on Humanities and Social Sciences, 4(6), 129-136. Retrieved from https://www.iiste.org/Journals/index.php/RHSS/article/view/11902/12243

Sharan, Y. (2015). Meaningful learning in the cooperative classroom, Education 3-13, 43(1), 83-94. https://doi.org/10.1080/03004279.2015.961723

Siagian, M. V., Sahat Saragih, S., \& Sinaga, B. (2019). Development of learning materials oriented on problem-based learning model to improve students' mathematical problem solving ability and metacognition ability. International Electronic Journal of Mathematics Education, 14(2), 331-340. https://doi.org/10.29333/iejme/5717

Steele, M. M. (2008). Teaching social studies to middle school students with learning problems. The Clearing House: A Journal of Educational Strategies, Issues and Ideas, 81(5), 197-200. https://doi.org/10.3200/TCHS.81.5.197-200

Stinson, M. S., \& Liu, Y. (1999). Participation of Deaf and Hard-of-Hearing Students in Classes with Hearing Students. Journal of Deaf Studies and Deaf Education, 4(3), 191-202. https://doi.org/10.1093/deafed/4.3.191

Triarini, W. D., Degeng, I. N. S., Efendi, M., \& Toenlioe, A. J. E. (2017). The effectiveness on the use of multimedia to improve basic reading skill of hearing-impaired students. European Journal of Special Education Research, 2(5), 36-49. https://doi.org/10.5281/zenodo.814053

Whitby, P. J. S., Leininger, M. L., \& Grillo, K. (2012). Tips for using interactive whiteboards to increase participation of students with disabilities. Teaching Exceptional Children, 44(6), 50-57. https://doi.org/10.1177/004005991204400605

Yin, R. (2012). Applications of case study research (3rd ed.). Sage Publications.

Yusuf, M., Sari, E. K., \& Mirasandi, I. P. (2017). The effect of concept sentence learning model in improving 
learning achievement of social sciences for student with hearing impairment. Advances in Social Science, Education and Humanities Research, 174, 650-653. https://doi.org/10.2991/ice-17.2018.138

Zarrillo, J. J. (2012). Teaching elementary social studies: Principles and applications (4th ed.). Pearson.

\section{Copyrights}

Copyright for this article is retained by the author(s), with first publication rights granted to the journal.

This is an open-access article distributed under the terms and conditions of the Creative Commons Attribution license (http://creativecommons.org/licenses/by/4.0/). 